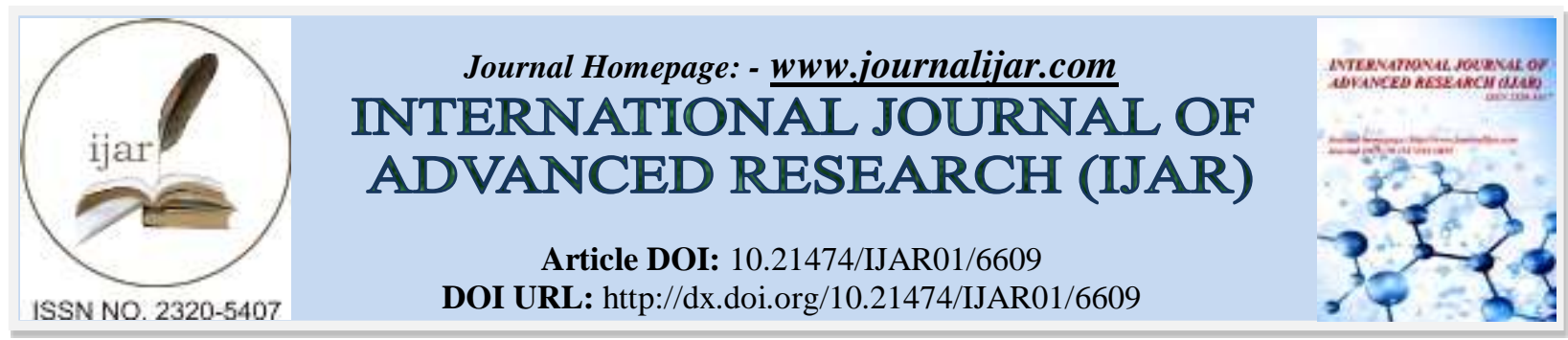

RESEARCH ARTICLE

\title{
CONCEPT OF CORPORATE CRIMINAL LIABILITY: AT A GLANCE WITH GLOBAL DEVELOPMENT.
}

Harpreet Singh ${ }^{1}$ Sachar and Dr. Praveen Kumar ${ }^{2}$.

1. Ph.D. Scholar, School of Law, The NorthCap University, Gurugram; Advocate, Punjab \& Haryana High Court, Chandigarh.

2. Ph.D Supervisor and Asst. Professor (Sel. Grade), School of Law, The NorthCap University, Gurugram.

\section{Manuscript Info}

\section{Manuscript History}

Received: 22 December 2017

Final Accepted: 24 January 2018

Published: February 2018

\section{Abstract}

A corporation is a different legitimate element built up through some enactment or enrollment prepare. They have rights and liabilities isolate from that of their shareholders. Some of these organizations have resources and offices in different nations separated from their nation of origin also and such enterprises are known as multinational corporations (MNCs). Multinational companies have come to assume a colossal part in many parts of human life today. Their forces have developed at an astounding rate in the course of the most recent few centuries, to such an extent that they are frequently contrasted with whole countries. Consequently, forcing some kind of methods for responsibility and control over these multinationals and organizations is of fundamental significance and ought to be to a great degree high on the rundown of needs for each country.

Copy Right, IJAR, 2018,. All rights reserved.

\section{Introduction:-}

This research is entitled on 'Corporate Criminal liability: Jurisprudence and its centrality in Indian Context' which is a standout amongst the most noteworthy subjects in the train of present day Criminal Law ${ }^{1}$. The two key subjects of this examination are:

(i) The theoretical elements which in the business world are known as Companies or Corporations, and

(ii) The threat of another sort of crimes which is known in the domain of criminal statute as corporate crimes. In an investigation of this kind it is important to note all things considered the occasions which have since occurred as to the previously mentioned organization and the way of violations connected with this specific establishment.

The criminal act ought to be perpetrated in advancement of the advantage of the enterprise and also the advantage of the agent. The beginning of corporate substance might be followed to the improvements that occurred in the Legal System in the wake of the rights and protection the law stood to the common people yet had denied the same to the non-characteristic people. Corporations are made criminally at risk in the event that they intentionally choose not to see to progressing criminal exercises. If a corporate agent ends up noticeably suspicious of some continuous unlawful acts however to maintain a strategic distance from culpability, he makes no move to relieve the harm or explore advance or convey the offender to book, the organization winds up noticeably liable.

\footnotetext{
${ }^{1}$ Abhimanyu Kumar, "Corporate Criminal liability”, Social Science Research Network, Aug 11 2009, pp. 1, Available at SSRN: https://ssrn.com, Last Visited on 03/05/2017, at 1:35 PM
} 
Under the principles of law, a characteristic individual had every one of the rights to exchange which he went into with respect to property, contracts or some other matters ${ }^{2}$. The result of such an inflexible approach of the legitimate framework was that there was no insurance given to the rights and protection of any conceptual substance. For the corporate what are clearly do harm to environment, the Government passed Air Pollution Act in 1981 to clean up our air by controlling contamination. It expresses that wellsprings of air contamination, for example, industry, vehicles, control plants, etc., are not allowed to discharge particulate matter, lead, carbon monoxide, sulfur dioxide, nitrogen oxide, unstable natural mixes (VOCs) or other poisonous substances past a recommended level ${ }^{3}$. The Common Law perceived the privileges of people in regard of property and other common relations in regard of regular people as it were. There was in this manner the idea of lawful proprietor, lawful bequest, lawful rights and protection and nothing else having a place with non-social people was perceived. In any case, from the seventeenth century onwards a critical change showed up in the legitimate relations and this was in the wake of the progression which the Sovereign had taken by setting up specific establishments like the Universities, the Churches, the Hospitals and altruistic foundations and gave on them the privilege to gain and hold property, to go into legally binding relations and to look for assurance to their rights in the official courtrooms ${ }^{4}$. One of the main cases of rights and protection conceded to extract elements is frequently cited as that of the East India Company which by a Charter was offered rights to execute its business with the abroad nations. Such an approach of the Royal power acquired a progressive change in the law administering the legitimate relations by giving such benefits and invulnerabilities to the unique elements.

1. Public Nuisance - Courts in England and the United States initially forced corporate criminal obligation in cases including non-back of semi open companies, for example, districts that brought about open disturbances.

2. Crimes not requiring criminal intent - As the presence and significance of Corporations developed, courts broadened corporate criminal obligation from open aggravation to all offenses that did not require criminal plan. This improvement inevitably urged courts to stretch out corporate criminal risk to all wrongdoings not requiring goal.

3. Crimes of intent - In A Company have none of elements that describe a living individual, a mind that can have information or aim or be careless. In any case, organization, being a body corporate can sue and be sued in its own name. In the statutes characterizing violations, the preclusion is much of the time coordinated against any individual who submits the denied demonstration, in numerous statutes the term - individual is characterized. ${ }^{5}$

4. Expansion of corporate criminal liability - The legislation made corporations subject for all offenses, developing criminal risk that had before and been restricted to monetary violations. The 1976 enactment additionally abstained from the prerequisite that risk be predicated on the activities of characteristic people following up for the partnership's sake, which was a necessity of the past 1951 laws $^{6}$. However, a standout amongst the most critical components favouring criminal risk over common obligation was that the general population common authorities did not have as much requirement control as criminal enforcers did.

\subsection{Definition of Corporate Criminal Liability}

Corporate crime implies violations submitted either by an enterprise, or by a person that might be related to a company. A corporate crime is the demonstration of its own and need not be approved or confirmed by its authorities. It is adequate if the authorities were practicing standard powers for the benefit of the company. In this way to significant degree, the crime of the company is entwined with the demonstrations of its authorities. Such criminal acts are intelligent of the character of the people who deal with the corporation.

Now, criminal liabilities of corporations are taking its sweep. The term corporate crime describes these corporate activities, which are perused to involve some aspects of criminal law. Corporate crime is commonly used to denote bridges of regularity offences. Corporate crime also includes fraud and other illegal activities, which affects general

\footnotetext{
${ }^{2}$ Agarwal.V.K., Seminar on Problems of Monopoly \& Company Law, (Bombay: N. M. Tripathi Private Ltd 1972).

${ }^{3}$ Air (Prevention and Control of Pollution) Act, 1981, Available at : http://www.envfor.nic.in/legis/air/air1.html, Last visit on 03/05/2017, at 2:07 PM

${ }^{4}$ Ahmad Siddique, Criminology, AfzalQadri, (Ed.), (5 ${ }^{\text {th }}$ Ed.) (Lucknow: Eastern Book Company 2009), OCLC No. 371197544

${ }^{5}$ K.G Balkrishanan J.in Standard Charted Bank v. Directorate Of Enforcement at p. 284 JT 2005 (5) SC 267; (2005) 4 SCC 50

${ }^{6}$ Dharm Veer Singh, Corporate Criminal Liability: A Jurisprudential and Comparative Approach, Available at: http://www.legalserviceindia.com, Last Visited on 03/05/2017, at 2:30PM
} 
laws. Criminal Liability is affixed quite recently those exhibits in which there is encroachment of Criminal Law i.e. to state there can't be hazard without a criminal law which blocks certain acts or omissions ${ }^{7}$.

\subsection{Corporate Criminal Liability under Indian Law}

"Corporate Crime has been dependably been in the news and can best be characterizing as unlawful acts carried out by corporate worker for the benefit of the organization and with its backings." The results are extensive and it is said to be extremely serious as company are dispensing a sort of harm to the general public that individual acting alone can't imagine incurring. "India ought to receive criminal risk in such manner is with analyzing to assess and watch which obligation would help hand down equity particularly after the Bhopal Gas Leak case which brought about mass decimation. It is considered as the world's most exceedingly awful mechanical disaster in 1984 where because of the break of methyl isocyanate gas and different substances at the Union Carbide India Limited (UCIL) pesticide plant in Bhopal, Madhya Pradesh, India, 500,000 individuals brought about being influenced and in spite of open responsibilities to wellbeing and security UCIL made or permitted to create conditions whereby a mischance was conceivable and additionally neglected to alleviate the impacts. Its repercussions are still observed today. Then, the Supreme Court judgment conveyed in 1996 by Justice Ali. M. Ahmadi is profoundly scrutinized for weakening the charges against the denounced where on a request of moved by the blamed, the Supreme Court had altered the charges from Section 304 Part (1) (at fault crime not adding up to murder) to Section 304-A (bringing about death by carelessness) of the Indian Penal Code 1860. On June seventh 2010, 26 years after the catastrophe, the trial of the blamed, generally previous authorities of the Union Carbide, finished up with a shockingly low discipline i.e. two years of detainment with a fine of Rs. 1 lakh under fundamental Section 304-A (bringing about death by carelessness) of the Indian Penal Code making it a bailable offense. The discipline does not legitimize the offense conferred on that repulsive night, which is the reason it has been assaulted from each corner" ${ }^{\prime 8}$. However the conviction of the denounced brought forward one certainty that the model embraced in India for corporate obligation is like that of UK i.e. ID as we see that the leader of the UCIL was charged for the offense ${ }^{9}$. Albeit today enterprises can be criminally subject however so far India has not enacted on corporate criminal risk like the US, UK or Australian. The statutes in India don't yet incorporate such created law consequently still makes the authority in charge of every single criminal act.

A few illustrations are Articles 45,63,68,70(5),203,542 and so forth of the Indian Companies Act 1956 which hold just the authorities of the organization at risk and not simply the organization and the different segments of the Indian Penal Code 1860 guides necessary detainment neglecting to consider a partnership since such an endorse can't conflict with the company. The Securities Contracts (Regulation) Act, 1956 "Act" ${ }^{10}$ was authorized keeping in mind the end goal to anticipate undesirable exchanges in securities and to direct the working of stock trades in the nation. A body corporate incorporated under the Companies Act, 1956 whether under a scheme of corporatization and demutualization or otherwise, for the purpose of assisting, regulating or controlling the business of buying, selling or dealing in securities. "Aside from the above in India certain enactments which have arrangements for corporate technique for obligation are Prevention of Food Adulteration Act, 1954 (Section 17), the Essential Commodities Act, 1955 (Section 10), the NDPS Act, 1985 (Section 38), the Trade Marks Act, 1999 (Section 114), the Income Tax Act, 1961 (Sections 276-C and 278-B)”. It is essential to examinations the upsides and downsides of corporate criminal risk and contrast it with common cures with finish up what is more reasonable or effective.

\subsubsection{Case Laws: Corporate Criminal Liability}

Standard Chartered Bank \& Ors. V Directorate of Enforcement \& Ors ${ }^{11}$, The Standard Chartered Bank had violated certain arrangements of the Foreign Exchange Regulation Act, 1973. For this situation it was watched that as on account of torts, the general decide wins that the organization might be criminally be at risk for the

\footnotetext{
${ }^{7}$ Abhishek Anand, Holding Corporations Directly Responsible for Their Criminal Acts: An Argument, http://www.manupatrafast.com, visited on 03/05/2017, at 2:40 PM.

${ }^{8}$ Miriam Maisonville, Rethinking Theories of Corporate Criminal liability in Criminal Law: pushing the legislative Envelope -a comparison of Canadian, American \& English developments, submitted to the International society for the Reform of Criminal law at the $20^{\text {th }}$ International Conference held at Vancouver BC Canada on June 22-256, 2007.

${ }^{9}$ Mahajan, Kartikey "Corporate Criminal Liability: Why Corporations are preferred \& not the employees ?" 04(01), Company law Journal 2008

${ }^{10}$ Securities Contract Regulation Act, 1956

${ }^{11}$ AIR 2005 SC 2622, Last Visited on 27/04/2017, at 4:45 PM
} 
demonstration of an officer or specialist and it.

In the case of State Trading Corporation of India $v$ Commercial Tax Officer $^{12}$ the court held that dissimilar to a unincorporated organization, which has no different presence and which the law does not recognizes from its individuals, a fused organization has isolate presence and the law remembers it as a lawful individual particular and unmistakable from its members. At the point when these corporations have isolated lawful element, it can possess property, can sue and can be sued. Presently the principle address emerges that whether these companies can be liable of carrying out a wrongdoing or not? What's more, when they are held liable would they be able to be punished for their criminal demonstration and if yes then what might be the punishment that can be forced upon them.

Tesco Supermarkets $v$ Nattrars $^{13}$, for this situation TESCO, an organization was putting forth washing powder at a marked down rate in a store, and it had shown in a notice. When they came up short on stock the organization pulled back the offer and supplanted the value stock. The trough neglected to illuminate and the clients were accused of higher cost. Thus TESCO was charged under the Trade Description Act, 1968 for erroneously promoting the cost of washing powder. In its defense Tesco expressed that the organization had avoided potential risk and all due perseverance, and that the lead of administrator is not appended to the enterprise.

Zee Telefilms Ltd. V. Sahara India Co. Corp. Ltd $(2001)^{14}$.For this situation the grievance charged that Zee had broadcasted a program in view of lie and had maligned Sahara India. Sahara had documented the objection under Section 500 of IPC. The conduct of the organizations and enterprises was damaging to social interests as a result of which the powers of the State made the stride of directing the lead of the organizations treating the lead of the organizations as corporate violations. The powers of the State have felt that that the wonder of corporate crimes is expected more to the issues of the association and working of the corporate elements other than the approaches of the State ${ }^{15}$. Hence, a few advisory groups have been designated in and outside India which have proposed certain changes for the sake of Corporate Governance.

Hence, an organization, in the business world, was viewed as free of the people who formed it. Such a corporate status in course of time was surrendered by the courts in regard of a few non-business elements as well. For instance, the instructive organizations, the healing centers and the religious establishments were viewed as having their very own corporate identity and the advantages that went to such elements.

People in general or business organizations which rose in course of time at the example of the powers of the State additionally guaranteed the benefits and resistances as were yielded with respect to business elements. This is the way the idea of corporate substances made its steps and turned into a noteworthy part of the business associations.

However another advancement of criticalness has been the rise of multi-national organizations which have accepted the accountability of working together with administrative foundations other than keeping up their unique character as business establishments and have looked to assert similar benefits which were implied for the business foundations. The organizations which rose in the changed setting welcomed the use of the standards of Public Law to the foundation of enterprise. This change was in the nature and working of the organizations which acquired them strife with law in a few matters.

The law has bound the Courts to force just fine as a type of the discipline for corporate which should be explained by developing and consolidating new types of the disciplines upon the corporate.With this paper, we are explaining the types of crimes made in the corporation, the way to recover from it.

The present study covers the review of corporate criminal risk under the Indian law. Corporate Crime is a crime done officially and is of a specific kind. Corporate crime is an authoritative wrongdoing happening with regards to complex connections and desires of Board of Directors, Executives and Managers and on the other hand by its other

\footnotetext{
${ }^{12} 1963$ AIR 1811, 1964 SCR (4) 89, Last Visited on 27/04/2017, at 9:55 AM

${ }^{13}$ [1972] AC 153, Last Visited On 27/04/2017, at11:15 AM.

${ }^{14}$ (2001) 1 CALLT $262 \mathrm{HC}$, Last Visited on 03/05/2017, at 3:45 PM

${ }^{15}$ Bangia, R.K. 'Company Law' (2 ${ }^{\text {nd }}$ Ed.), (Allahabad Law Agency, 1999).
} 
employees due to delegated legislation in big enterprises as well as Multinational Corporations. The corporate crime has developed gradually over the years.

Corporate crimes demonstrate that corporate lawbreakers cover a very wide range of misbehaviors, much of its serious: among these violations is accounting malpractice, false statement of corporate assets, unfair labour practice etc. The amount of loss to exchequer has been much bigger due to corporate crimes.

The corporate criminals are not handled by the criminal law even though they are large in number. There is dilemma as to which law to be applied and which crimes are recognized by the existing laws. Corporate responsibility and government with regards to a criminal prosecution is best taken a gender at as far as immediate and insurance results. The immediate outcome of this is criminal liability. Everybody in the corporate chain of importance can be prosecuted for criminal action, officers, executives, workers, even the partnership itself. The security outcomes of a criminal indictment can rise above the budgetary obligation coming about because of a criminal trial. Among these guarantee outcomes are loss of government contracts and shareholder claims.

"In the cutting edge world, the solid impact of exercises of partnerships is mind boggling on the general public. In the everyday exercises, and not exclusively do organizations influence the lives of the general population as a gift additionally numerous a times demonstrates shocking which then falls under the classification of wrongdoings.

The criminal law jurisprudence identifying with inconvenience of the criminal risk on partnerships is settled on the point it is the enterprises can carry out violations and consequently be made criminally obligated. Be that as it may, the statutes in India are not in pace with these advancements and the above examination indicates it they don't make partnerships criminally at risk and regardless of the possibility that they do as such, the statutes and legal understandings force no different disciplines aside from fines. Aside from fines, disciplines, for example, ending up of the organization, to transitory conclusion of the corporate, substantial remuneration to the casualties, by venturing on the shortcoming of the company i.e., its goodwill and so forth. Such methods for the discipline will deterrent affect the corporate and the sole point of discipline under criminal law would be accomplished". 